\title{
BACK NumBers
}

\section{of the \\ AMERICAN JOURNAL OF INTERNATIONAL LAW}

\section{and \\ PROCEEDINGS OF THE AMERICAN SOCIETY OF INTERNATIONAL LAW}

THE Society has in stock a limited supply of back numbers of the Journal in the original paper bindings for sale at $\$ 7.50$ an issue, as follows:

Complete volumes of the Journal are available for the years 1964, 1966, 1968, 1969 and 1970. Numbers available for other years are: 1919: January, April, July; 1931, 1967 : January, A pril, October; 1927, 1930, 1951, 1963, 1965: April, July, October; 1925, 1943: April, July; 1921, 1928, 1936, 1938, 1949, 1959, 1960, 1961: July, October; 1922, 1953: January; 1926, 1934, 1952, 1957 : July; 1918, 1929, 1937, 1947, 1955, 1962: October.

Supplement, 1935, Part I: Harvard Research Draft Convention and Comment on Extradition. 1928.

Special Supplements (paper or cloth): 1917, 1926,

Single issues of the current volume (1971) may be obtained at $\$ 6.00$ a copy.

Proceedings are available for the years 1956-1958, $1961-1963,1965-1969$ at $\$ 7.50$ a volume.

Analytical Index to the Journal and Supplements, Vols. 35-54 (1941-1960) and Proceedings of the Society, 1941-1960. Cloth, $\$ 20.00$.

Orders should be sent to the

American Journal of International Law

2223 Massachusetts Avenue, N. W., Washington, D. C. 20008 


\section{The Procedural Aspects of International Law Series}

Richard B. Lillich, Editor

"The whole series represents a most valuable contribution."

-International and Comparative Law Quarterly

1. International Claims:

Their Adjudication by National Commissions

Richard B. Lillich

2. International Claims:

Their Preparation and Presentation

Richard B. Lillich and Gordon A. Christenson

$\$ 6.50$

3. The Role of Domestic Courts in the

International Legal Order

Richard A. Falk

4. The Use of Experts by International Tribunals Gillian White

5. The Protection of Foreign Investment:

Six Procedural Studies

Richard B. Lillich

$\$ 7.50$

6. International Claims: Postwar British Practice Richard B. Lillich

7. Law-Making in the

International Civil Aviation Organization

Thomas Buergenthal

$\$ 10.50$

8. UN Protection of Civil and Political Rights John Carey

9. International Claims: Postwar French Practice Burns H. Weston

In July . . .

10. International Law, National Tribunals, and the Rights of Aliens

Frank G. Dawson and Ivan L. Head 


\title{
REBELLION, RACISM, AND REPRESENTATION
}

The Adam Clayton Powell Case and Its Antecedents

P. Allan Dionisopoulos

What Constitutional limits-if any-are imposed upon Congress when it refuses to seat elected representatives? In the past, such issues as polygamy (John M. Bernhisel and Brigham Roberts), loyalty and patriotism (former Confederates), citizenship after slavery (Hiram Revels), socialismpacifism (Victor Berger), and misconduct before election (John C. Conner, B. F. Whittemore, Arthur R. Gould) became-for both chambers-the excuse to exercise broad, political interpretations of vague Constitutional powers. In this book, Professor Dionisopoulos makes the plea that Congress set up definite, self-imposed guidelines to be used impartially in judging the qualifications of members of the House and Senate, and he warns us that failure to abide by Constitutional principles in seating members-elect seriously jeopardizes the entire democratic process.

$\mathrm{x} / 175$ pages

LC 76-125335

ISBN 0-87580-018-1 (cloth) \$6.50

ISBN 0-87580-504-3 (paper) $\$ 2.50$

NORTHERN ILLINOIS UNIVERSITY PRESS DeKalb, Illinois 60115

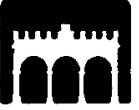

\section{International Summer Course on Legal Aspects of European Integration}

\author{
'Europa Instituut', University of Amsterdam \\ August 16-28, 1971
}

Participation is open to lawyers, legal advisers in enterprises, and civil servants confronted with problems raised by the EEC Treaty. Tuition fee: Dfl. 600.(approx. \$167.00)

Full Information: Netherlands Universities Foundation for International Co-operation (NUFFIC), 27 Molenstraat, The Hague, Netherlands 


\title{
NEW FROM YALE
}

\section{NULLITY AND REVISION}

\section{The Review and Enforcement of International Judgments and Awards}

\author{
by W. Michael Reisman
}

The process of resolving international disputes by authoritative decisions and bringing such decisions and future conduct into harmony with each other is a problem of the utmost importance. Adapting the policy-oriented framework of Myres McDougal and Harold Lasswell, the author takes up comprehensively the entire subject of international arbitration and decision.

Mr. Reisman develops a set of sequential heuristic models, which enable the international decision-maker to orient himself in the flow of pre-decision, decision, and post-decision events, and permit him to formulate the most effective decision. He then treats in depth a selective but wide range of claims lodged against the validity of a decision, at different sequences, and considers in detail the policies and the contextual investigations to which they should be subjected. Finally, Mr. Reisman presents a model of enforcement for international awards and judgments based on the availability of effective power in diverse contexts and the intricate network of authority expectations that decision-makers may activate and integrate in the enforcement process.

Y A Yale University Press- New Haven and London

L $\mathbf{E}$ in Canada: McGill-Queen's University Press

\section{The Soviet Union and the Law of the Sea}

\section{WILLIAM BUTLER}

This book is the most thorough study published in any language of the Soviet approach to maritime law. Russian legislation, treaties, judicial decisions, diplomatic practice, and legal writings are thoroughly analyzed and placed in the context of political and technological developments and historical precedent. Political scientists, jurists, and diplomats will find this comprehensive and systematic discussion invaluable.

$\$ 12.00$

\section{THE JOHNS HOPKINS PRESS}

Baltimore, Maryland 21218 


\section{A mirror of Chinese life}
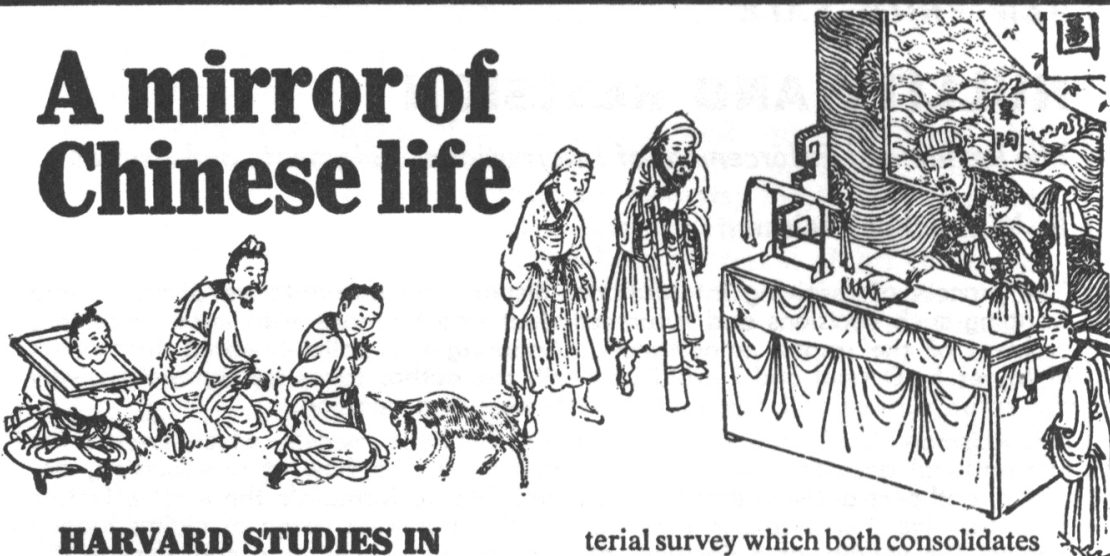

\section{HARVARD STUDIES IN} EAST ASIAN LAW

Jerome Alan Cohen, Chairman

of the Editorial Committee

Only in the last decade have American scholars become aware of the value that the study of law can have to an understanding of the evolution of Chinese social, economic, and political life. This important new series provides new insights into the traditions, theoretical bases, and workings of East Asian law.

\section{CONTEMPORARY CAIINESE LAW:}

Research Problems and Perspec. tives. Edited by Jerome Alan Cohen. Thirteen essays that explore the methodology for studying Chinese law and investigate research materials, analyze terminology problems, and discuss the comparison's between the Chinese legal system and our own and that of the U.S.S.R.

“...It will be praised by men concerned with seeking the universal insistence of social order. The authors have proved that China is not chaotic, although it presents less familiar features of social order than any other of the great families of law."-Harvard Law Review \$10.00

\section{LAW IN IMPERIAL CHINA:}

Exemplified by 190 Ch'ing Dynasty Cases (translated from the Hsing-an hui-lan) with Historical, Social, and Judicial Commentaries. By Derk Bodde and Clarence Morris. "A landmark for the subject - a magis- terial survey which both consolidates and amplifies previous work $\$ 17.50$

\section{THE CRIMINAL PROCESS IN THE PEOPLE'S REPUBLIC OF CHINA, 1949-1963:}

An Introduction. By Jerome Alan Cohen. "... one of the most revealing books yet published concerning the sociopolitical life of the ordinary Chinese on the Mainland." - The Annals of the American Academy of Political and Social Sciences.

\section{AGREEMENTS OF THE PEOPLE'S REPUBLC OF CHINA, 1949-1967:}

A Calendar. By Douglas Millar Johnston and Hungdah Chiu. "Serious students of. China and international law will be deeply indebted to the prodigious labor and impressive scholarship which this seminal reference work represents." - Harvard International Law Journal.

A new brochure describing all our books on Asia is available upon request.

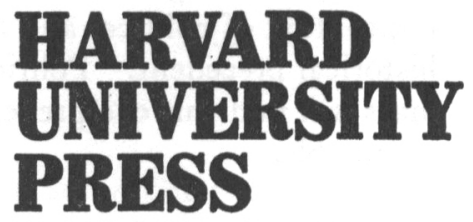

Cambridge, Mass. 02138 


\section{STANDING ORDER SERVICE}

To be sure of receiving the latest titles in International Law-or any of a number of other categories-use our Standing Order Service. You will then automatically get such new titles as:

International Review of Criminal Policy No. 28, 1970

$\$ 2.00$

Multilateral Treaties in Respect of which the SecretaryGeneral performs Depositary Functions

International Court of Justice Yearbook

1966-67 No. 314- $\$ 1.50$

1967-68 No. 324-\$1.50

1968-69 No. 334-\$2.00

SEND FOR OUR STANDING ORDER BROCHURE

United Nations

Publications

Room LX-2300

New York, N.Y. 10017
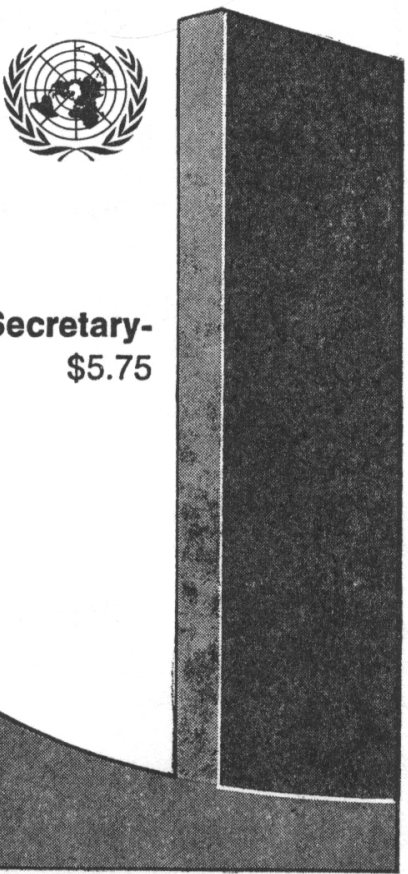


\title{
REPRINT
}

\section{PROCEEDINGS OF THE AMERICAN SOCIETY OF INTERNATIONAL LAW}

Volumes 1-49 (1907-1955)

\author{
Complete Set Clothbound $\$ 489.00$ \\ Paperbound \$432.00 \\ Per Volume Paperbound $\$ 9.00$
}

Volumes 12 and 13 (1918-1919) combined and priced as one volume.

Reprinted by Special Arrangement with

The American Society of International Law

Address all orders and inquiries to:

\section{KRAUS REPRINT CO.}

A U.S. Division of

Kraus-Thomson Organization Limited

16 East 46th Street

New York, N.Y. 10017 


\section{Expanding International Law in a Shrinking World}

\section{OCEANA PUBLICATIONS, INC. • DOBBS FERRY, NEW YORK}

Under the guidance of Francis Deak, Consultant in International Affairs, Oceana has in recent years taken the leadership in the publication of significant titles in the field. The objectives of its extensive publication program are summarized below, and its fruits are reflected in the pages which follow.

I.

Objective: To combine the best scholarship and editorial skill with the most advanced reproduction techniques to produce source and documentary materials consolidated for student reference and professional research.

Oceana publishes the Consolidated Treaty Series and acts as distributor of the League of Nations Treaty Series, so that the total range of treaties of the past 300 years is made readily available at one source.

To facilitate the examination of national statements and interpretations of international law, Oceana has begun publication of American International Law Cases and Italian International Law Practice, and it has co-published British International Law Cases with Stevens \& Sons of London.

And with the re-issue of the International Law Quarterly and the Grotius Society Transactions for the British Institute of International and Comparative Law and International Legislation and World Court Reports for the Carnegie Endowment for International Peace, Oceana has begun a program of reprinting some of the long out-of-print classics in the field.

\section{II.}

Objective: To provide a publishing medium to specialists and opinion moulders for the analysis of contemporary international issues in the context of domestic and international implications.

Oceana has published the Hammarskjöld Forum Series for the Association of the Bar of the City of New York; and it has selectively published and co-published monographs which, in its view, represent important contributions to the current literature of international affairs.

It also publishes for and with major institutions and organizations in the field-the American Society of International Law, the Inter-American Institute of International Legal Studies, the International Institute for the Unification of Private Law (Unidroit), and the Parker School of Foreign and Comparative Law, as well as those mentioned above.

The mention of specific works is not intended to exclude other important publications in a growing list that encompasses International Law through Treaties, Public and Private International Law, and international commercial and investment law. Oceana seeks a balanced publication program. Its efforts are designed to expand the availability of both scholarly reference works and practical material of importance to the international law practitioner, e.g., the Digest of Commercial Laws of the World.

- Treaty Series

- International Law Practice

- American Society of International Law Publications

- The Hammarskjöld Forums and The Parker School Publications
- Monographs in International Law and Relations

- International Law Catalogs and Reprints

- Document Collections and Encyclopedia

- Foreign Commercial and Investment Law 


\section{THE CONSOLIDATED TREATY SERIES, 1648-1918}

\section{Edited and annotated by Clive Parry, LL.D., Cambridge University}

The Consolidated Treaty Series begins with the year 1648, the year of the Treaties of Muenster and Osnabrueck which established the European system of states. It terminates in 1918, with the advent of the League of Nations Treaty Series.

The Series reproduces treaties concluded between 1648 and 1918 from numerous earlier series and, in some cases, from original documents in government archives. It represents the first attempt to consolidate in a single collection all available treaties over this 270 -year period.

An essential feature is the annotations which cover detail as to the parties to a given treaty, its termination or continued effect, and its continuing relevance. Where the original language is neither English nor French, either a contemporary translation or a summary in English of the main treaty provisions is furnished.

The Series is sponsored by Council of Europe, British Institute of International and Comparative Law and the American Society of International Law.

SBN: $379-13000-9$

LC \#70-76750

100 plus volumes projected

$\$ 40$. per volume

25 volumes now published

\section{LEAGUE OF NATIONS TREATY SERIES and \\ General Indexes to the Treaty Series}

A collection of multilateral and bilateral treaties registered with the League of Nations from 1918 to 1945, when the United Nations Treaty Series begins. Treaties are printed in both English and French. Where original language was other than these two, text also appears in the original.

SBN: $379-13200-1$

$\$ 2,500$. the set

205 volumes, 9 index volumes

(Library-bound)

The combination of the Consolidated Treaty Series, the League of Nations Treaty Series and the United Nations Treaty Series (both available from Oceana) offers the totality of treaties entered into by national states from the beginnings of modern times to the present.

\section{League of Nations Documents}

Oceana Publications has acquired the total holdings of the League of Nations Depository in Geneva. We offer the following:

Four partial sets are offered, consisting of 1,400 to 1,500 separate items. An invaluable source of detailed reference in studying world affairs of the crucial $1920^{\prime}$ s and 1930's. Collection covers a wide range of political, social and economic papers. $\$ 2,500$. the set

\section{League of Nations Official Journal}

Official Journal of the League of Nations, 1920-1940 (mostly English, some in French). Approximately 2,000 pages xeroxed. Paperbound. (Will bind into at least 40 volumes.) 


\section{LEAGUE OF NATIONS AND UNITED NATIONS MONTHLY LIST OF SELECTED ARTICLES \\ Cumulative, 1920-1970}

\section{A Cumulative Index to 3,000 periodicals throughout the World}

Covering 50 years of periodical articles in the fields of international, constitutional and administrative law, politics and economics, the Monthly List of Selected Articles is being published by Oceana in a multi-volume series, the first two volumes of which are now available. Each volume will consist of approximately 400 pages.

The only cumulative form in which this material now exists is a card catalog begun by the League of Nations in 1920 and continued since 1945 by the United Nations at its Geneva Library.

Oceana will publish the reproduction of that card file, containing chronologically listed entries by subject and country, extracted from some 3,000 periodicals from all over the world. This is a total of some quarter-million card entries, covering the areas of (1) Political Questions (2) Legal Questions and (3) Economics and Population.

Upon completion, the work will be the outstanding bibliographical tool in the field of periodical literature in international law and relations.

SBN: $379-14150-7$

LC \#75-147817

Vols. I, II now available

$8 \frac{1}{2} \times 11$ double column format

$\$ 50.00$ per volume

\section{Additional Titles on Treaty Series, Materials and Commentary}

Rosenne, Shabtai, Guide to Legislative History of the Vienna Convention on the Law of Treaties, Co-published with Sijthoff.

SBN: 379-00464-X $\quad$ \$25. per volume $\quad$ LC \#74-131422

Al-Baharna, Husain M., The Legal Status of the Arabian Gulf States-A Study of Their Treaty Relations and Their International Problems

SBN: $379-00379-1$

355 pages

1969

LC \#68-57676

$\$ 7.50$

Bot, B. R., Non-Recognition and Treaty Relations

SBN: $379-00372-2$

301 pages

1968

$\$ 10$.

Bowett, D. W., The Law of the Sea

SBN: 379-11907-2 126 pages

$1967 \$ \$ 6.00$

LC \#66-29654

Fadel, H. A.; Malha, J.; Craidy, I., Lebanon-Its Treaties and Agreements

SBN: 379-00334-1

4 volumes

1967

LC \#67-18401

Holloway, K., Modern Trends in Treaty Law

SBN: $379-00345-7$

760 pages

1967

$\$ 95$.

Inter-American Institute of International Legal Studies, Instruments Relating to the Economic Integration of Latin America

SBN: $379-00338-4$

464 pages

1968

LC \#67-23682 $\$ 12.50$

Parry, Clive, Sources and Evidences of International Law

SBN: 379-11904-8

120 pages

1965

LC \#65-17525

$\$ 5.50$

University of the Philippines Law Center, editor, Philippine Treaty Series SBN: 379-16050-1

4 volumes

1968-1969

$\$ 120$. the set

Snee, J. M. \& Pye, K. A., Status of Forces Agreements and Criminal Jurisdiction SBN: $379-11601-4$

167 pages

1957

LC \#57-12991

$\$ 8$.

United States Department of State, Catalogue of Treaties, 1814-1918 


\section{AMERICAN INTERNATIONAL LAW CASES Compiled and edited by Francis Deak, Rutgers- The State University}

A collection of American Federal and State Court decisions involving questions of public international law during the period from 1783 through 1968. The task was undertaken by Professor Francis Deak, Professor of International Law at Rutgers Law School, Camden, N. J.

Until now, the thousands of cases interpreting and applying international law (whether customary or treaty law), are scattered among tens of thousands of Federal and State reports and the volumes of the National Reporter System. Now this collection makes available to the community of international legal scholars the significant American international law decisions of the past 185 years. The decisions are annotated where appropriate-especially with precise identification of and citation to treaties which underlie the majority of the cases. Interim indexes will be published, and a cumulative index will appear when the set is complete.

SBN: $379-20075-9$

LC \#78-140621

Vol. I available April, 1971

\$40. per volume

8-10 volumes projected

\section{BRITISH INTERNATIONAL LAW CASES \\ Edited by Clive Parry, Cambridge University}

This monumental collection of British court cases setting forth and interpreting international law was prepared under the auspices of the International Law Fund and the British Institute of International and Comparative Law. Its eight volumes contain more than 7500 pages of cases.

Vols. I-VII available now

Vol. VIII available April, 1971

Vol. I: $\$ 18.75$

Vol. II: $\$ 28.00$

Vol. III: $\$ 27.00$

SBN: $379-14020-9$
Vol. IV: $\$ 27.50$

Vol. V: $\$ 24.00$

Vol. VI: $\$ 30.00$
Vol. VII: $\$ 30.00$

Vol. VIII: $\$ 35.00$

LC \#63-22348

\section{ITALIAN INTERNATIONAL LAW PRACTICE 1861-1942}

Compiled by The Italian Society for International Organization, under the general editorship of Professor Roberto Ago.

Following a model proposal of the Council of Europe, the Italian Society began about five years ago to compile all the Italian diplomatic papers in the Italian Foreign Office, with a view to publishing this Digest. It will furnish a detailed picture of Italian international law practice from the birth of the Italian State till the end of the Second World War. Many of the papers have never been previously published.

Ten volumes are projected for the series. Text is in Italian, although for future volumes, headnotes will be in both Italian and English. Index is in English-French-Italian. 


\section{AMERICAN SOCIETY OF INTERNATIONAL LAW Co-Publications}

Oceana is pleased and proud to list the following titles which it has published for and in close cooperation with the American Society of International Law. Each of the first four titles listed below is an outgrowth of a conference of official legal advisers convoked by the Society.

Merillat, H. C. L., ed., Legal Advisers and Foreign Affairs. SBN: 379-00223-X. $\$ 4.25$

Merillat, H. C. L., ed., Legal Advisers and International Organizations. SBN: 379-00294-9. $\quad \$ 4.00$

Schwebel, S. M., ed., The Effectiveness of International Decisions. SBN: 37900462-3. $\$ 19.50$ ( $\$ 14.60$ to Society members placing orders through the Society offices)

Rubin, S. J., ed, Foreign Development Lending-Legal aspects. SBN: 379-00129-2. (Price and publication date to be announced)

Leive, D. M., International Telecommunications and International Law: The Regulation of the Radio Spectrum. SBN: 379-00458-5. $\$ 16.50$ (\$12.65 to Society members placing orders through the Society offices)

\section{THE PARKER SCHOOL OF FOREIGN AND COMPARATIVE LAW, COLUMBIA UNIVERSITY}

\section{Bilateral Studies in Private International Law}

These practical guides to the legal relations of individuals in the international sphere are written by outstanding legal scholars.

1. Nussbaum, A. American-Swiss 2nd ed. SBN: 379-11401-1 94 pp. 1958

2. Delaume, G. American-French 2nd ed.

SBN: 379-11402-X 221 pp. 1961

3. Kollewijn, R. D. American-Dutch 2nd ed.

SBN: 379-11403-8 111 pp. 1962

4. Domke, 'M. American-German (2nd ed. by U. Drobnig due 1971)

SBN: 379-11404-6 144 pp. 1956

5. Eder, P. J. American-Colombian SBN: 379-11405-4 95 pp. 1956

6. Ehrenzweig, A. A., Fragistas, Yiannopoulos, American-Greek SBN: 379-11406-2 111 pp. 1957

7. Philip, A. American-Danish SBN: 379-11407-0 80 pp.

8. Cowen, Z. American-Australian SBN: 379-11408-9 108 pp. 1957
9. Garland, P. G. American-Brazilian SBN: 379-11409-7 125 pp. 1959

10. Etcheberry, O. American-Chilean SBN: 379-11410-0 96 pp. 1960

11. Seidl-Hohenveldern, I. American-Austrian

SBN: 379-11411-9 220 pp. 1963

12. Ehrenzweig, Ikehara, Jensen American-Japanese

SBN: 379-11412-7 176 pp. 1964

13. Nial, H. American-Swedish SBN: 379-11413-5 111 pp. 1965

14. Lombard, R. S. American-Venezuelan

SBN: $379-11414-3 \quad 128$ pp. 1965

15. Goldschmidt, W., Rodriguez-Novas, Jose American-Argentine

SBN: $379-11415-1 \quad 118$ pp. 1967

16. Ansay, Tugrul American-Turkish SBN: 379-11416-X 115 pp. 1966

17. Van Hecke, G. American-Belgian SBN: $379-11417-8 \quad 128$ pp. 1968

Each volume is $\$ 7.50$ 


\section{THE HAMMARSKJÖLD FORUMS}

\section{Sponsored by the Association of the Bar of the City of New York}

1. The Issues in the Berlin-German Crisis, working paper by R. R. Bowie, edited by Lyman $\mathrm{M}$. Tondel, Jr. SBN: 379-11801-7 96 pp. $1963 \$ 5.00$

2. The Role of the United Nations in the Congo, working paper by T. M. Franck and J. Carey, edited by Lyman M. Tondel, Jr.

SBN: 379-11802-5 160 pp. $1963 \$ 6.50$

3. The Inter-American Security System and the Cuban Crisis, working paper by $C$. Oliver, edited by Lyman $M$. Tondel, Jr.

SBN: 379-11803-3 112 pp. $1964 \$ 6.00$

4. Disarmament, working paper by $\mathrm{L}$. Henkin, edited by Lyman M. Tondel, Jr.

SBN: 379-11804-1 112 pp. $1964 \$ 6.00$

5. The International Position of Communist China, working paper by $\mathrm{O}$. E. Clubb and E. Seligman, edited by Lyman M. Tondel, Jr.

SBN: 379-11805-X 128 pp. $1965 \$ 6.00$

6. The Panama Canal, working paper by R. R. Baxter and D. Carroll, edited by Lyman $\mathrm{M}$. Tondel, Jr.

SBN: 379-11806-8 128 pp. $1965 \$ 6.00$

7. The Aftermath of Sabbatino, working paper by R. A. Falk, edited by Lyman M. Tondel, Jr.

SBN: $379-11807-6240$ pp. $1965 \$ 9.00$
8. The Southeast Asia Crisis, working paper by K. T. Young, Jr., edited by John Carey

SBN: 379-11808-4 228 pp. $1965 \$ 8.00$

9. The Dominican Republic Crisis, working paper by $\mathrm{A}$. J. Thomas and $\mathbf{A}$. Thomas, edited by John Carey

SBN: 379-11809-2 192 pp. $1967 \$ 7.00$

10. Race, Peace, Law and Southern Africa, working paper by $\mathrm{H}$. J. Taubenfeld and R. F. Taubenfeld, edited by John Carey

SBN: 379-11810-6 240 pp. $1967 \$ 9.00$

11. Law and Policymaking for Trade Among "Have" and "Have Not" Nations, working paper by Stanley D. Metzger, edited by John Carey

SBN: 379-11811-4 128 pp. $1968 \$ 6.00$

12. International Protection of Human Rights, edited and author of working paper-John Carey

SBN: 379-11812-2 128 pp. $1968 \$ 6.00$

13. The Middle East: Prospects for Peace, working paper by Quincy Wright, edited by Isaac Shapiro

SBN: 379-11813-0 113 pp. $1969 \$ 6.00$

14. When Battle Rages, How Can Law Protect?, working paper by Howard S. Levie, edited by John Carey

SBN: 379-11814-9 128 pp. $1971 \$ 7.50$

15. The Cambodian Incursion-Legal Issues, edited by Donald T. Fox

SBN: 379-11815-7 128 pp. $1971 \$ 7.50$

Just published ....

When Battle Rages, How Can Law Protect? John Carey, editor

A much-needed discussion of the problem of respect for human rights in armed conflict, this book takes on special meaning when we read of the bombings of civilian populations and follow the trials coming from the alleged Vietnam massacres. In the working paper, Howard S. Levie, Professor of Law, St. Louis University, sets the stage by pointing out: "Armed conflict is, by its very nature, unhumanitarian. However, humanitarian rules, properly applied, can do much to mitigate this situation."

Other participants include: Marc Schreiber, Director of the Human Rights Division, United Nations; Richard R. Baxter, Professor, Harvard Law School; and Richard D. McCarthy, member of Congress, New York.

The Cambodian Incursion-Legal Issues, Donald T. Fox, editor

Soon after the President's announcement of the movement of U. S. forces into Cambodia in Spring of 1970, the Association of the Bar of the City of New York agreed to sponsor a discussion of the legal issues raised by this action. The discussion was held in the form of a debate on May 28, 1970. Both the issues concerning the U.S. Constitution and those concerned with International Law were debated.

Participants were: William H. Rehnquist, Assistant Attorney-General, Office of Legal Counsel, U. S. Department of Justice; Robert B. McKay, Dean, New York University School of Law; John R. Stevenson, Legal Adviser, U. S. Department of State; and Abram Chayes, Professor of Law, Harvard University, former Legal Adviser, U. S. Department of State. An introduction has been prepared by Andreas F. Lowenfeld, Professor of Law, New York University, formerly Deputy Legal Adviser, U. S. Department of State. 


\section{MONOGRAPHS IN INTERNATIONAL LAW}

\section{A Partial Listing *}

\section{Codification}

Dhokalia, R. P., The Codification of Public International Law. SBN: 37900264-7. $\$ 12.50$

\section{Diplomacy}

Hardy, M., Modern Diplomatic Law. Melland-Schill Series. SBN: 379-11908-0. $\$ 5.50$

Kaufmann, J., Conference Diplomacy-An Introductory Analysis. SBN: 37900374-0. $\$ 7.00$

Regala, R., World Order and Diplomacy. SBN: 379-00438-0. $\quad \$ 9.00$

Foreign Policy

Higgins, R., The Administration of United Kingdom Foreign Policy Through the United Nations. Maxwell School Series. SBN: 379-12101-8. $\$ 3.50$

Fenwick, C., Foreign Policy and International Law. SBN: 00366-X. $\$ 6.00$

Schleicher, C. P. \& Bains, J. S., The Administration of Indian Foreign Policy Through the United Nations. Maxwell School Series. SBN: 379-12103-4. $\$ 5.00$

Schwarz, U., Confrontation and Intervention in the Modern World. SBN: 379. 00380-5. $\$ 7.50$

International Adjudication

Anand, R. P., Studies in International Adjudication. SBN: 379-00466-1. \$6.25

Cukwurah, A. O., The Settlement of Boundary Disputes in International Law. SBN: $379-00241-8 . \quad \$ 8.00$

International Communication

Leive, D. M., International Telecommunications and International Law: The Regulation of the Radio Spectrum. SBN: 379-00458-5. $\$ 16.50$

McWhinney, E., The International Law of Communications. SBN: 379-00138-1. $\$ 8.00$

\section{International Rivers}

Garretson, A. H., Olmstead, C. J. \& Hayton, R. D., The Law of International Drainage Basins. SBN: 379-00320-1. \$31.00

Outer Space and International Law

Fawcett, J. E. S., International Law and the Uses of Outer Space. MellandSchill Series. SBN: 379-11909-9. $\$ 4.00$

Gal, G., Space Law. SBN: 379-00290-6. \$11.00

McWhinney, E., New Frontiers in Space Law. SBN: 379-00389-9. $\$ \$ 7.50$

Recognition

Bot, B. R., Non-recognition and Treaty Relations. SBN: 379-00373-2. $\$ 10.00$

United Nations

Gutteridge, J., The United Nations in a Changing World. Melland-Schill Series. SBN: 379-11910-2. $\$ 5.00$

Chamberlin, W., Hovet, T. H. \& Hovet, E., Chronology and Fact Book of the United Nations, 3rd Edition. SBN: 379-00453-4. $\$ 7.50$

- Catalog available on request. 


\section{Harvard Law School Library}

\section{CATALOG OF INTERNATIONAL LAW AND . RELATIONS}

A comprehensive bibliography of international law and related subjects representing the complete holding of the Library's collection, accumulated through concentrated effort over more than a century. Margaret Moody, Assistant Librarian for Cataloging, Harvard Law School Library, is the Editor of the set.

Distributed exclusively by Oceana.

SBN: 379-20003-1 20 vols.

1965-67

$\$ 1,000$ the set

\section{CAMBRIDGE CATALOG OF INTERNATIONAL LAW}

Prepared by Willi Steiner, Institute of Advanced Legal Studies, University of London, for the Squire Library

Cambridge University Law School has prepared one of the first catalogs of international law to be done on computer. Compiled in four volumes, totalling some 2,000 pages, the catalog features author, title and subject matter indexes, with strong emphasis on treaties and documents.

Available June, 1971.

SBN: $379-20030-9$

4 volumes, $\$ 200$. the set

\section{INTERNATIONAL LAW REPRINTS}

Carnegie Endowment for

International Peace

\section{WORLD COURT REPORTS}

A collection of the judgments, orders and opinions of the Permanent Court of International Justice, edited by Manley O. Hudson. Information and instruments relative to the Court are also included. Numerous tables, lists and indices add to the usefulness of these Reports.

The set consists of four volumes: Vol. I, 1922-26; Vol. II, 1927-1932; Vol. III, 1932-35; Vol. IV, 1936-42

SBN: $379-00428-34$ volumes

$\$ 50$. per volume

$\$ 140$. the set

INTERNATIONAL LEGISLATION Hudson, Manley, $O$.

The following annotation is from $A$ Catalogue of the Law Collection at New York University (page 589): “. . . International Legislation; a collection of the texts of multipartite international instruments of general interest beginning with the Covenant of the League of Nations."

volumes 1,2 available $\$ 50$. per volume, $\$ 400$. the 9-volume set
British Institute of International and Comparative Law GROTIUS SOCIETY TRANSACTIONS

The Grotius Society was formed in 1915 in London for study, discussion and advancement of public and private international law, and to make proposals for reform. Its Transactions during 1915-1959 include contributions by practically every authority in the field. Co-published by the British Institute of International Law with Wildy \& Sons, Ltd., London.

SBN: $379-20500-9 \quad 45$ volumes

$\$ 15$. per volume $\$ 500$. the set

The Index:

$\begin{array}{lcc}\text { SBN: } & 379-20545-9 & 128 \mathrm{pp} . \\ 1969 & \$ 15 .\end{array}$

INTERNATIONAL LAW QUARTERLY

This is a reprint of the four-volume set which was the predecessor of the International and Comparative Law Quarterly

\$125. the set

\section{EGYPTIAN REVIEW OF INTERNATIONAL LAW}

The only international law periodical in the Near East, the Review is highly regarded in the world of scholarship. Its field of interest is a wide one and includes all the varied problems of international law arising in the Near East. On the documentary side, the Review publishes much material not otherwise accessible to the researcher.

SBN: $379-12400-9$

25 volumes 1969

$\$ 380$. the set, cloth/D $\$ 17.50$ per volume 


\section{BASIC DOCUMENTS OF AFRICAN REGIONAL ORGANIZATIONS}

\section{Edited by Louis B. Sohn, Bemis Professor of International Law, Harvard University, and Counselor on International Law, United States Department of State.}

This 3-4 volume set is a unique collection of annotated documents dealing with the development of regional organization in Africa.

All basic agreements, as well as subsidiary rules of procedure of all African regional organizations are reproduced in English or French. Each chapter contains introductory notes setting forth the historical and political events from which the organization emerged and the various states of development, activities and action of each. An extensive bibliography follows each introductory note, providing references to official sources of basic and supplementary documents, books and treatises, articles and periodicals, and including works in English, French, German and Italian.

The main sub-divisions in the approximately 1800-page manuscript are:

Organization of African Unity

The African Development Bank

Regional Groups in French-Speaking Africa

Regional Cooperation in West Africa

Published under the auspices of the Inter-American Institute of International Legal Studies, Washington, D. C.

SBN: 379-00361-9

Volume I now available

4 Volumes projected
The Maghreb Permanent Consultative Committee

The East African Organizations

The Association of African States with the European Economic Community.

\section{CONSTITUTIONS OF THE COUNTRIES OF THE WORLD} Permanent Loose-Leaf Edition

Compiled with Chronologies and Bibliographies by ALBERT P. BLAUSTEIN, Rutgers-Camden Law School and GISBERT FLANZ, New York University

Projected as a ten-volume loose-leaf set, the service will be regularly updated to reflect constitutional changes and to permit the inclusion of new and revised constitutions. The end product will be the only permanent and continuous research and information service on the constitutions of all countries.

Volume I consists of a one-star loose-leaf binder, together with approximately 1,000 pages of material covering the constitutions of: Ecuador, Fiji, Gambia, Ghana, Korea, Malawi, Malta, Paraguay, Turkey, Uruguay, Western Samoa, and Yugoslavia. Now available.

So that payment may be equated with issue of material, the set is priced at $\$ 5.75$ per Constitution (only full issues of material may be ordered). This includes not only the constitution itself and the attendant annotative material, but binders as they become necessary and all supplementary and revised material as it is issued until the set is complete. (Such supplementary and revised material will be issued as needed, so that each constitution is kept up-to-date on a continuing basis.)

SBN: $379-00467-4$

Vol. 1- $\$ 69.00$ including binder

\section{IN'TERNATIONAL ENCYCLOPEDIA OF COMPARATIVE LAW}

Conceived under the auspices of UNESCO, sponsored by the International Association of Legal Science, and compiled under the aegis of the Max Planck Institute, Konrad Zweigert, general editor, this monumental 16-volume (17-book) set is expected to emerge as the definitive work in comparative law in our times. A chief editor and advisory group of some five-to-seven experts are charged with the preparation of each volume. In all, 350 experts from all over the world have served as rapporteurs. It is anticipated that the project will take approximately seven years to complete.

Accordingly, publication has been arranged in a combination of paperback individual subject matter pamphlets which ultimately will be grouped into the clothbound volumes, each of which is broken down into subject fields of law.

Price is $\$ 95.00$ per volume, payable on a unique installment plan to coincide with the issue of both paperback and clothbound material. Write to Oceana to request detailed prospectus and terms of subscription. 
Oceana also publishes in the area of International Commercial Law and Foreign Trade. We encourage those interested to subscribe to our Foreign Trade Newsletter (no charge) and to request our Catalogue of Books on Foreign Trade. Requests should be addressed to Oceana on your letterhead.

\section{DIGEST OF COMMERCIAL LAWS OF THE WORLD}

Edited since 1966 by the National Association of Credit Management under the direction of Dr. George Kohlik, Director, International Department, this four-binder loose-leaf service now covers sixty-five nations of the world, including the U.S.S.R. and major socialist countries. A new section-Forms of Contracts-is designed to facilitate transactions between nationals of different countries. Digest material is issued in quarterly supplements.

Subscription, beginning to May, 1972

Renewal subscription, May, 1971 to May, 1972

LC \#65-22163

$\$ 235$.

$\$ 75$.

\section{PATENTS AND TRADEMARKS}

As a separate service, the Editors of the Digest offer a binder on Patents and Trademarks with a subscription service that keeps the material up to date on a quarterly basis. Coverage of the laws of more than sixty countries.

Subscription, beginning to May, $1972 \quad \$ 75$.

Renewal subscription, May, 1971 to May, 1972 \$35.

\section{INTERNATIONAL INSTITUTE FOR THE UNIFICATION OF} PRIVATE LAW (UNIDROIT)

Oceana is exclusive distributor of all the publications of Unidroit, founded to promote on a world-wide scale the unification of law in the fields of private and commercial law.

Uniform Law Cases, 2 issues per year, multilingual with preference to English and French, collects selected decisions of various national courts of law in the application of rules and uniform law.

Complete set, 1959-1970

$\$ 137.50$

Yearly subscription:

Yearbook, the annual English/French survey of the Institute's activity includes special studies on unification of law, draft conventions, bibliographies, etc.

18-volume set through 1969

$\$ 151.50$

Standing Order for future.

Proceedings and Papers is a microfilm edition covering the activity of the Institute from 1928 to 1965 . $1966-1969$ is currently in preparation.

Microfilm edition through 1965 is priced at

$\$ 1,350$.

Digest of Legal Activities of International Organizations and other Institutions is an English/French loose-leaf publication aimed at covering the different phases of development of all legal activities undertaken by international organizations and institutions on private and public law.

Published in 1970-more than $450 \mathrm{pp}$.

Price of supplements to be announced.

$\$ 30$. standing order 